\title{
The value of cardiac troponin-i as a biochemical markers of acute coronary syndromes compared with other traditional markers
}

\author{
Basant A Abd Elrahman ${ }^{1}$, El Sharkawi $F^{1}$, Gamal M Shaban², Karam A \\ Mahdy ${ }^{3}$, Elmazar $M^{4}$ \\ ${ }^{1}$ Biochemistry Department Faculty of Pharmacy, Helwan University \\ ${ }^{2}$ National Heart Institute in Egypt \\ ${ }^{3}$ Medical Biochemistry Department, National Research Center in Egypt \\ ${ }^{4}$ Faculty of Pharmacy, British University in Egypt
}

\begin{abstract}
The aim of the present study was to assess the clinical values of serum total Creatine Kinase (Total-CK), Creatine Kinase-MB isoenzyme (CK-MB) and total Lactate Dehydrogenase (LDH) compared with cardiac Troponin-I (CTnI) in the diagnosis of acute coronary syndromes (ACS). The study was carried on 27 patients with acute coronary syndromes from the intensive care unit (ICU) of the Egyptian National Heart Institute (NHI), Imbaba, Giza, Egypt, in addition to 9 healthy age matched subjects served as controls. Patients were classified into 3 groups: Unstable angina group, acute myocardial infarction group with ST-segment elevation and myocardial infarction group with non ST-segment elevation. Blood samples have been taken from the patients on admission to NHI (ICU) and at 24 and 48 hours after their admission. Serum Total-CK, CK-MB, LDH were determined spectrophotometrically and CTnI was determined using Enzyme Linked Immunosorbent Assay (ELISA). The obtained results revealed that there was a positive significant correlation between $\mathrm{CTnI}$ and the other biochemical markers except with LDH on admission to NHI (ICU). Percent sensitivity was also determined. On admission both CTnI and CK-MB showed the highest sensitivity (59\%) while after 24 hours of admission, cTnI showed the highest sensitivity (85\%) and after 48 hours of admission LDH showed the highest sensitivity (77 \%). Specificity level 100\%.

In conclusion, the present study showed that cTnI was the most sensitive biochemical marker than the other traditional biochemical markers (Total-CK, CK$M B$, and $L D H$ ) for establishing the diagnosis of ACS during the first 48 hours after admission to the hospital. It is better, however to use a combination of more than one marker in the diagnosis of Acute Coronary Syndrome.
\end{abstract}

Key Words: Cardiovascular diseases, Serum Biochemical Markers.

\section{INTRODUCTION}

Acute coronary syndromes (ACS) represent a severity spectrum of coronary artery diseases ranging from suspected unstable angina through acute myocardial infarction ${ }^{(1)}$. Unstable angina has been described as a clinical syndrome between stable 
angina and acute myocardial infarction $^{(2)}$.

The Egyptian National Heart Institute (NHI) received 416975 patients with suspected cardiovascular diseases in the emergency department during the year 2005; 5308 (1.2\%) of them entered the Intensive Care Unit. Open heart surgery and percutaneous coronary interventions were carried out for $1682(0.4 \%)$ and 10815 (2.6 $\%)$ of these patients respectively (Information Centre of the National Heart Institute, personal communication).

Cardiovascular diseases are increased in men especially those with concomitant metabolic syndromes (diabetes mellitus, hypertension and hyperlipidemia). Early identification, treatment, and prevention of these metabolic syndromes represent a major challenge for health care professionals facing an epidemic of overweight and sedentary lifestyle ${ }^{(3)}$. The biochemical markers of myocardial injury are one of the three criteria for the diagnosis of acute myocardial infarction (4). The diagnosis of acute myocardial infarction (AMI) and unstable angina is based on typical clinical signs, electrocardiogram (ECG) changes, and serial measurements of characteristic serum enzymes ${ }^{(5)}$.

The initial marker of interest used to quantitate infarct size was total Creatine kinase (Total-CK), which evolved to CK-MB fraction (CK-MB) when practical assays for the isoenzyme became available ${ }^{(6)}$.

LDH determination for the diagnosis of acute myocardial infarction should be reserved for cases in which the CK has already fallen to normal or when infarction is suspected to have occurred 2 to 4 days before admission to $\mathrm{ICU}^{(7)}$. The discovery of cardiac Troponins has herald a new age in the diagnosis and treatment or management of a broad spectrum of diseases, grouped together under the heading of acute coronary syndromes and including stable and unstable angina, and NonST-segment elevation myocardial infarction to ST-segment elevation infarction. Cardiac Troponins, which are selectively released by damaged myocardiocytes, have specificity that they have not only allowed an improvement in the diagnosis of acute cardiac ischemic disorders, but also enabled us to make a more reliable stratification of risk prediction of outcome $^{(\mathbf{8})}$.

Serum cardiac Troponin-I elevation was initially detected with ischemic myocardial necrosis, but subsequently it has been reported with reversible ischemic myocardial injury such as in unstable angina, reversible non-ischemic myocardial injury such as in myocarditis, cardiac contusion and chemotherapy-induced myocardial injury $(9,10,11)$.

The aim of this study is to asses the best biochemical marker or markers which aid in the diagnosis of acute coronary syndromes, when the patient admitted to the hospital and at 24 hours and 48 hours after their admission.

\section{SUBJECTS \&METHODS}

Thirty six subjects were included in the present study, 27 patients with ACS from the Emergency Department of the ICU of The Egyptian National 
Heart Institute (21 males and 6 females), in addition to 9 healthy individuals served as controls.

Blood samples were collected from these patients as soon as they admitted to the ICU, and at 24 hours and 48 hours after admission. Also, blood samples were collected from the 9 healthy subjects. Sera were separated and stored at $-80{ }^{\circ} \mathrm{C}$ until analysis. All subjects were classified into four groups:

Group I: Included 9 male patients with Unstable Angina (UA) with Mean \pm SE age of $58 \pm 4.13$ years.

Group II: Included 8 males and 1 female with Acute Myocardial Infarction with ST- segment elevation (STEMI) with mean age of $53 \pm 2.95$ years.

Group III: Included 4 males and 5 females with Acute Myocardial Infarction with non ST-segment elevation (NSTEMI) with mean age of $58 \pm 3.18$ years.

Group IV: Control group included 4 males and 5 females with mean age of $52 \pm 1.72 \quad$ years.

All groups (control and patients) were subjected to complete physical and clinical examinations to exclude the presence of previous or recent hepatic or renal disorders. Also, electrocardiogram (ECG) was done for primary diagnosis of acute coronary syndromes (Unstable angina) and (myocardial infarction).

Laboratory assessments:

The following biochemical markers were determined.

* Serum Total-CK:

Serum total-CK was quantitatively measured according to the kinetic procedure $^{(12)}$. Kits were provided by Stanbio Laboratory, USA.
* Serum CK-MB Isoenzyme:

Serum CK-MB was quantitatively measured according to the kinetic procedure (Immuno-inhibition method) ${ }^{(\mathbf{1 3})}$. Kits were provided from Cal-Test Diagnostics, Inc. USA.

* Serum LDH:

Serum LDH was quantitatively measured by the spectrophotometric method $^{(\mathbf{1 4})}$. Kits were provided by Sera Pak (AMES), England.

* Serum cardiac Troponin-I:

Serum cardiac Troponin-I was quantitatively measured by ELISA (Sandwich technique) $^{(\mathbf{1 5})}$. Kits were provided by DRG International, Inc, USA.

\section{Statistical analysis:}

The data obtained was presented in tables as mean \pm standard error. To analyze two sets of data unpaired Student's t-test was used to test the difference in age. To analyze more than two sets of data ordinary one way analysis of variance (ANOVA) for parametric data was tried first followed by Tukey-Kramer multiple comparisons test when Bartlett's test for homogeneity of variance was notsignificant. If Bartlett's test was significant logarithmic transformation of the individual data was performed before testing ANOVA again and then followed by Tukey-Kramer when Bartlett's test became not-significant. If logarithmic transformation did not reduce variability between individual values shown as significant difference of Bartlett's test the comparison was carried out using ANOVA for nonparametric data followed by Dunn's test. Also, clinical correlations were determined by least square method. 
Percent sensitivity and specificity were also determined for each marker. Sensitivity $=a /(a+c)$

Specificity $=d /(b+d)$

Where $\mathrm{a}=$ Disease positive and test result positive

$\mathrm{b}=$ Disease negative and test result negative

$\mathrm{c}=$ Disease positive and test result negative

$\mathrm{d}=$ Disease negative and test result negative

The diagnostic accuracy at different cut-off values were calculated by ROC method ${ }^{(\mathbf{1 6})}$.

\section{RESULTS}

The current study included 27 patients with Acute Coronary Syndromes (ACS). Their characters were shown in Table (1). The mean ages were $57 \pm 2$ years for patients with acute coronary syndromes and 52 \pm 1.7 years for the control group. Eighteen patients were suffering from hypertension, 6 were suffering from diabetes mellitus and 9 were smokers . The effect of smoking, hypertension and diabetes within the three patients groups was tested using Chi-square method and was found to be nonsignificant. For smoking $\left(\mathrm{X}^{2}=3, \mathrm{P}=\right.$ $0.2231)$, for hypertension $\left(X^{2}=3, P=\right.$ $0.2231)$ and for diabetes $\left(X^{2}=1.286\right.$, $\mathrm{P}=0.5258)$

In the present study, the serum levels of the detected cardiac markers Total-CK, CK-MB, LDH and cTnI were determined on admission to ICU, and at 24 hours and 48 hours after ICU admission and were expressed as Mean $\pm \mathrm{SE}$ and the significance from the control group or within the groups was tested statistically as shown in Table (2).

It was found that the mean serum level of Total-CK for the STEMI group was significantly higher than that of the control group on admission, 24 hours and 48 hours after admission to the ICU $(\mathrm{P}<0.05)$. For the NSTEMI group it was significantly higher than that of the control group, on admission and 24 hours only $(\mathrm{P}<0.05)$.

Also, it was found that the mean serum levels of CK-MB for the STEMI and NSTEMI groups was significantly higher than that of the control group on admission, 24 hours and 48 hours after admission to the ICU $(\mathrm{P}<0.01)$. It was also found that there was a significant difference in the mean serum levels of CK-MB between the UA group and STEMI group on admission to ICU $(\mathrm{P}<0.05)$.

On the other hand, it was found that the mean serum level of LDH for the STEMI group was significantly higher than that of the control group on admission $(\mathrm{P}<0.01), 24$ hours and 48 hours after admission to the ICU (P $<0.01)$. For the NSTEMI group it was significantly higher than that of the control group on admission only $(\mathrm{P}<$ $0.01)$.

In addition, it was found that the mean serum level of cTnI for the STEMI and NSTEMI groups was significantly higher than that of the control group on admission, 24 hours and 48 hours after admission to the ICU $(\mathrm{P}<0.01)$, while for the UA group, it was significantly higher than that of the control group on admission only $(\mathrm{P}<0.01)$.

In the present study, it was shown that there was a positive significant 
correlation between cTnI level and Total-CK, CK-MB for all of patient groups on admission, 24 hours and 48 hours after admission to ICU. For $\mathrm{LDH}$, however, the positive significant correlation was found at 24 and 48 hours after admission only (Table 3).

Sensitivity levels for all cardiac biochemical markers were calculated and presented in table (4). On admission both cTnI and CK-MB showed the highest sensitivity (59\%) while after 24 hours of ICU admission
cTnI showed the highest sensitivity (85\%) and after 48 hours of ICU admission LDH showed highest sensitivity $(77 \%)$. For all cardiac markers the percent specificity was $100 \%$.

Diagnostic accuracy of the cardiac biochemical markers at different reference cut-off values were tested, on admission to ICU and after 24 and 48 hours. It was observed that cTnI was the most sensitive and specific marker at 24 hours after ICU admission (Fig 1, 2 and 3).

Table (1): Patient's Characteristics Compared With Control Groups.

\begin{tabular}{lcccc}
\hline Character & Control Group & $\begin{array}{c}\text { UA } \\
(\mathrm{n}=9)\end{array}$ & $\begin{array}{c}\text { STEMI } \\
(\mathrm{n}=9)\end{array}$ & $\begin{array}{r}\text { NSTEMI } \\
(\mathrm{n}=9)\end{array}$ \\
\hline Male: & 4 & 9 & 8 & 4 \\
Female: & 5 & 0 & 1 & 5 \\
Age: & & & & \\
(Mean \pm SE) & $52 \pm 1.72$ & $58 \pm 4.13$ & $53 \pm 2.95$ & $58 \pm 3.18$ \\
Hypertension: & 0 & $5(55.5 \%)$ & $8(88.8 \%)$ & $5(55.5 \%)$ \\
Diabetes: & 0 & $1(11.1 \%)$ & $3(33.3)$ & $2(22.2 \%)$ \\
Smoking: & 0 & $4(44.4 \%)$ & $4(44.4 \%)$ & $1(11.15)$ \\
\hline
\end{tabular}

UA: Patients with Unstable angina.

STEMI: Patients with Acute Myocardial Infarction with segment elevation.

NSTEMI: Patients with Acute Myocardial Infarction with non ST- segment elevation. 
Table (2): Mean serum levels of cardiac biochemical markers for UA, STEMI and NSTEMI, on admission and at 24 and 48 hours after ICU admission.

\begin{tabular}{|c|c|c|c|c|}
\hline \multicolumn{5}{|c|}{ Total-CK (U/L) } \\
\hline & Control & UA & STEMI & NSTEMI \\
\hline Adm & $78 \pm 7.66$ & $186 \pm 68$ & $679 \pm 387 *$ & $592 \pm 193 *$ \\
\hline $24 \mathrm{hr}$ & & $465 \pm 212$ & $1590 \pm 764^{*}$ & $900 \pm 291 *$ \\
\hline $48 \mathrm{hr}$ & & $176 \pm 46$ & $683 \pm 366 *$ & $441 \pm 133$ \\
\hline \multicolumn{5}{|c|}{ CK-MB (U/L) } \\
\hline Adm & $7 \pm 0.95$ & $\begin{array}{r}25.6 \\
\pm 9.5\end{array}$ & $73 \pm 36 * *$ & $65 \pm 23 * *$ \\
\hline $24 \mathrm{hr}$ & & $50 \pm 21$ & $164 \pm 74 * *$ & $87 \pm 28 * *$ \\
\hline $48 \mathrm{hr}$ & & $21 \pm 5.5$ & $74 \pm 28.5 * * \bullet$ & $54 \pm 16 * *$ \\
\hline \multicolumn{5}{|c|}{ LDH (U/L) } \\
\hline Adm & $246 \pm 22.5$ & $436 \pm 82$ & $649 \pm 190 * *$ & $499 \pm 55 * *$ \\
\hline $24 \mathrm{hr}$ & & $636 \pm 139$ & $1486 \pm 348 * *$ & $979 \pm 308$ \\
\hline $48 \mathrm{hr}$ & & $668 \pm 128$ & $1450 \pm 440 * *$ & $962 \pm 299$ \\
\hline \multicolumn{5}{|c|}{ cTnI (ng/ml) } \\
\hline Adm & $1.57 \pm 0.03$ & $2 \pm 0.06 * *$ & $8.6 \pm 2 * *$ & $10 \pm 3.6^{* *}$ \\
\hline $24 \mathrm{hr}$ & & $10 \pm 3.5$ & $68 \pm 21 * *$ & $39 \pm 16 * *$ \\
\hline $48 \mathrm{hr}$ & & $6 \pm 2.2$ & $77 \pm 37 * *$ & $23 \pm 10 * *$ \\
\hline
\end{tabular}

* = Significant difference as compared with control group $(p<0.05)$.

$* *$ Significant difference as compared with control group $(p<0.01)$

- = Significant difference as compared with UA group $(p<0.05)$. (See methodology)

Table (3): Correlation between troponin-I and total-CK, CK- MB and LDH for all patients, on admission and at 24 hours and 48 hours after ICU admission.

\begin{tabular}{|c|c|c|c|}
\hline \multicolumn{4}{|c|}{ Troponin-I (cTnI) } \\
\hline & $\begin{array}{l}\text { On admission } \\
(\mathrm{n}=27)\end{array}$ & $\begin{array}{l}\text { After } 24 \text { hrs } \\
(n=27)\end{array}$ & $\begin{array}{c}\text { After } 48 \mathrm{hrs} \\
(\mathrm{n}=27)\end{array}$ \\
\hline Total-CK & $\begin{array}{c}\mathrm{r}=0.4611 \\
\mathrm{p}<0.05\end{array}$ & $\begin{array}{l}r=0.7293 \\
p<0.001\end{array}$ & $\begin{array}{l}r=0.7952 \\
p<0.001\end{array}$ \\
\hline CK-MB & $\begin{array}{c}r=0.4461 \\
p<0.05\end{array}$ & $\begin{array}{l}r=0.7277 \\
p<0.001\end{array}$ & $\begin{array}{l}r=0.7656 \\
p<0.001\end{array}$ \\
\hline $\mathrm{LDH}$ & $\begin{array}{c}\mathrm{r}=0.3271 \\
\mathrm{NS}\end{array}$ & $\begin{array}{l}r=0.7835 \\
p<0.001\end{array}$ & $\begin{array}{l}r=0.8438 \\
p<0.001\end{array}$ \\
\hline
\end{tabular}


Table (4): Sensitivity levels of cardiac biochemical markers for all patients, on admission and at 24 hours and 48 hours after ICU admission.

\begin{tabular}{|c|c|c|c|}
\hline & Admission & $24 \mathrm{hrs}$ & $48 \mathrm{hrs}$ \\
\hline Total-CK (\%) & 44 & 70 & 59 \\
\hline CK-MB (\%) & 59 & 66 & 55 \\
\hline LDH (\%) & 55 & 74 & 77 \\
\hline cTnI (\%) & 59 & 85 & 70 \\
\hline
\end{tabular}

Specificity levels for all markers were $100 \%$.

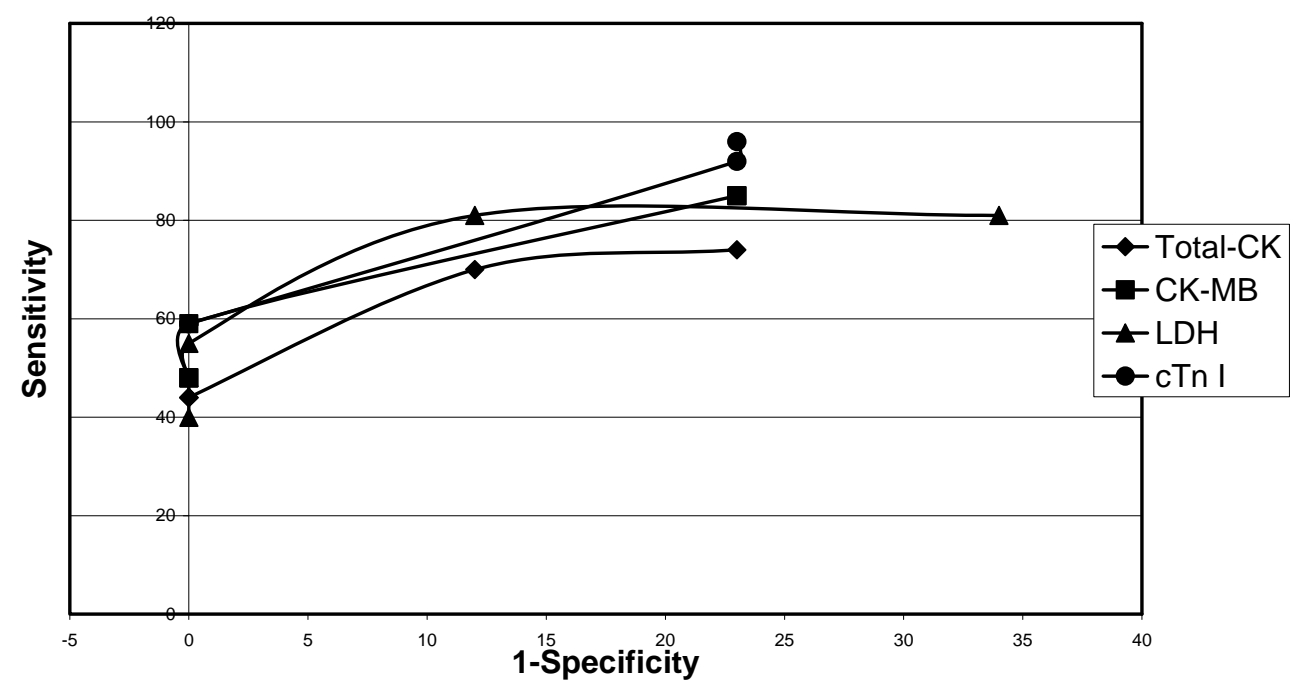

Figure (1): Diagnostic accuracy of the cardiac biochemical markers at different reference cut-off values on ICU admission. 


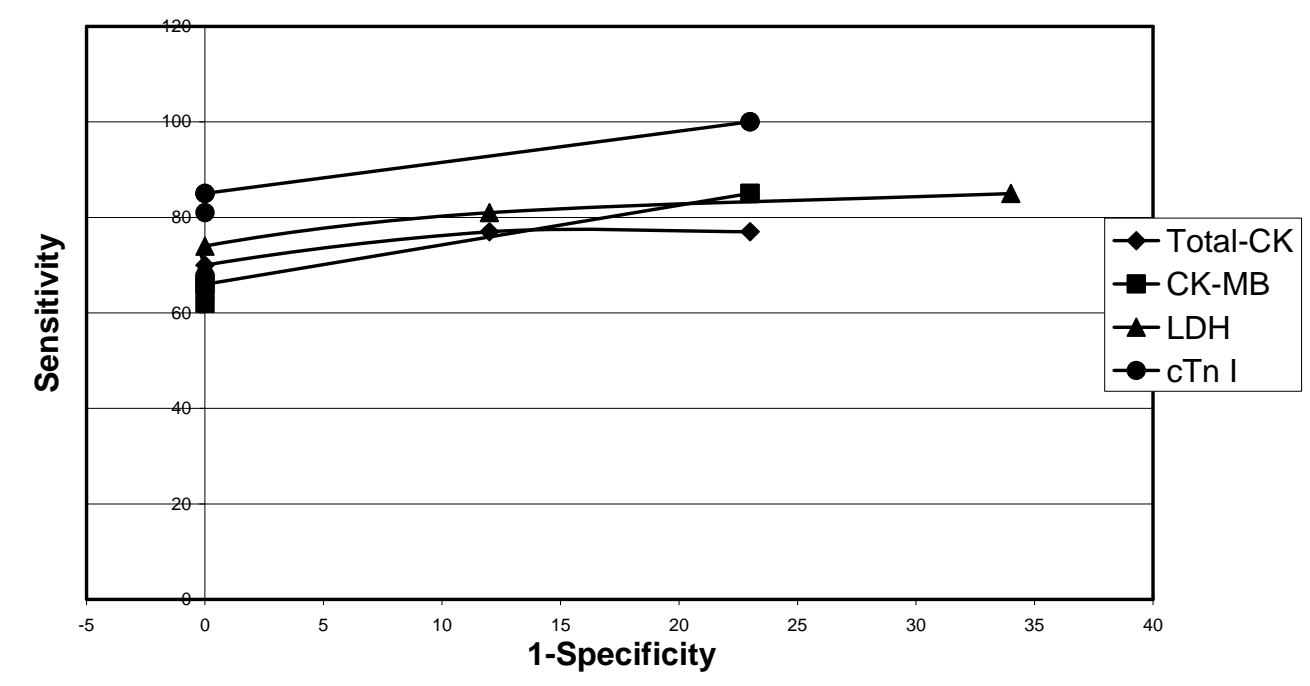

Figure (2): Diagnostic accuracy of the cardiac biochemical markers at different reference cut-off values at 24 hours after ICU admission.

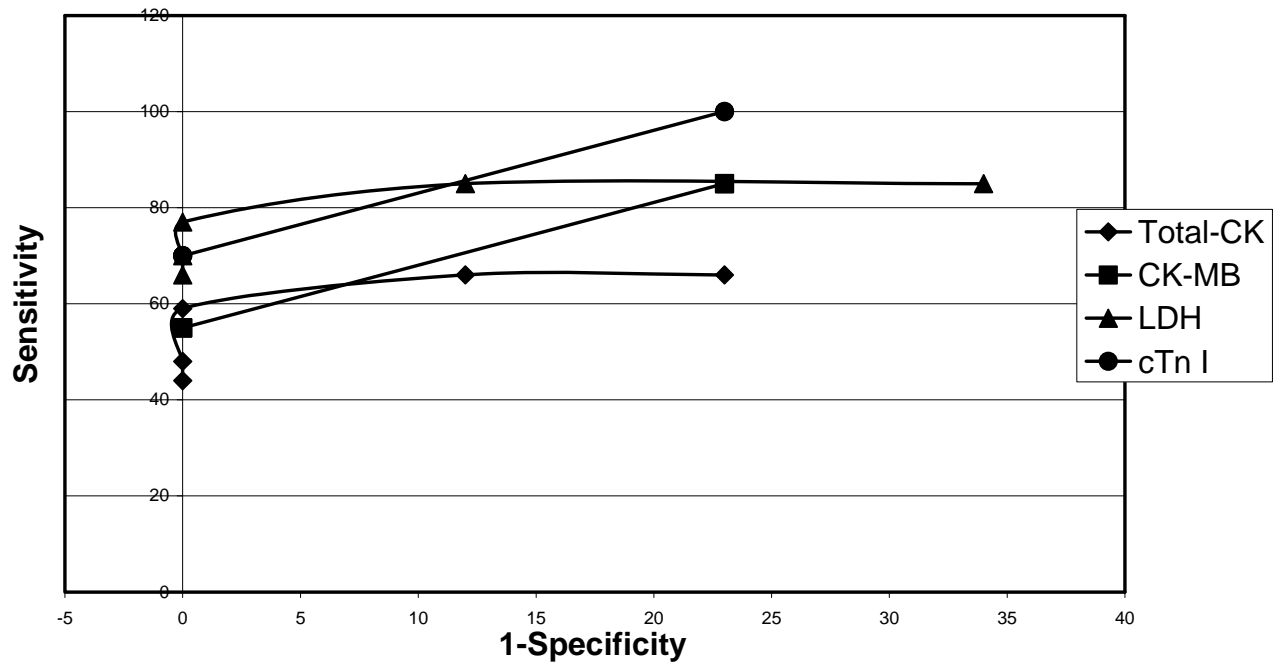

Figure (3): Diagnostic accuracy of the cardiac biochemical markers at different reference cut-off values at 48 hours after ICU admission. 


\section{DISCUSSION}

Coronary heart disease is the most common cause of death in both women and men in large parts of the industrialized world ${ }^{(\mathbf{1 7})}$. In the present study determination of serum levels of different cardiac enzymes was carried out for evaluation of the best laboratory marker for diagnoses of acute coronary syndrome (ACS).

Creatine kinase was the initial marker used to quantitate infarct $\operatorname{size}^{(6)}$. It was reported that serum level of Total-CK began to increase within 4 to 8 hours after the onset of AMI, reached its mean peak after 24 hours and declined to normal range within 3 to 4 days after the onset of the chest pain ${ }^{(\mathbf{1 8})}$. In the present study, the mean serum level of Total-CK of the patients was found to be elevated significantly from that of the control in STEMI group on admission to ICU of the NHI, 24 and 48 hours after admission $(\mathrm{P}<0.05)$ while in NSTEMI group it is elevated significantly on admission and after 24 hours only $(\mathrm{P}<0.05)$.

Creatine Kinase-MB Isoenzyme (CK-MB) activity was reported to be increased 2 to 3 hours after AMI, reached its peak within 4 to 8 hours, and returned to normal levels within 1 to 4 days ${ }^{(19)}$. In the present study, the mean serum CK-MB activity was found to be elevated significantly than that of the control in STEMI and NSTEMI groups on admission, 24 hours and 48 hours after ICU admission $(\mathrm{P}<0.01)$. It was, also, observed that the mean serum CK-MB level in STEMI group was elevated significantly than that of UA group at
48 hours after ICU admission $(\mathrm{P}<0.05)$.

Serum Lactate Dehydrogenase (LDH) was found to be elevated within 12 to 18 hours after the onset of AMI, peaked at $48-72$ hours and returned to normal after 6 to 10 days ${ }^{(\mathbf{2 0})}$. In the present study the mean serum level of LDH was found to be elevated significantly than that of the control in STEMI group on admission $(p<0.01), 24$ hours and 48 hours after admission $\quad(\mathrm{P}<0.001)$, while in NSTEMI group it was elevated significantly on admission only $(\mathrm{P}<0.01)$.

Recently, cardiac Troponin I (cTnI) is considered to be the most preferable biomarker of acute myocardial infarction ${ }^{(17)}$, since its level in the blood remains for longer period after myocardial damage than the level of CK-MB ${ }^{(21)}$.

In the present study, the mean serum level of cTnI was found to be elevated significantly in STEMI, NSTEMI groups on admission, 24 hours and 48 hours post ICU admission $(\mathrm{P}<0.01)$ while in UA group it was elevated significantly on admission only $(\mathrm{P}<0.01)$. These results are in accordance with another study which reported that the assay of cardiac-specific Troponins is a sensitive and specific means to diagnose unstable coronary artery diseases ${ }^{(22)}$. On the other hand, It was found that transient mild elevation of cTnI levels in patients is associated with an increase in major cardiovascular complications $^{(23)}$.

It is clear from the present results, there was a positive significant correlation between serum level of cTnI, Total-CK and CK-MB activities 
on admission, 24 hours and 48 hours post admission and with LDH after 24 hours and 48 hours post admission. Therefore, cTnI can be used as a marker for diagnosis of ACS and can replace the other classical markers, but it is preferred to use two markers with each other to confirm the results. It was found that two markers must be used in the diagnosis of ACS the first being the early one as myoglobin, isoform of Creatine Kinase which is very sensitive and can be detected in the first two hours after myocardial damage and the second marker is confirmatory. Confirmation of myocardial damage can be obtained by definite markers (Troponin-I or T) which are highly specific of myocardial damage ${ }^{(24)}$. It was reported that combining Troponins with other cardiac biomarkers may offer complimentary information on the underlying pathobiology and prognosis in an individual patient ${ }^{(25)}$. Also, It was demonstrated that an integration of biomarkers (TnI and CK-MB), ECG will help to identify false-positive ACS patients and avoid inappropriate admissions to Coronary Care Unit ${ }^{(26)}$. In addition, it was reported that combination of the measurements might further help in the identification of patients who would benefit from early coronary revascularization $^{(27)}$.

It is obvious from the present study that patients with UA showed slightly elevated cTnI while those with myocardial infarction showed higher levels of cTnI. These results are in accordance with another study which found that higher cTnI values were associated with worse outcomes. Although low cTnI values are associated with adverse events, these did not have the same implication as higher cTnI values ${ }^{(28)}$. That finding was, also, supported by another study ${ }^{(29)}$ which reported that among patients with ACS, even low-level elevations of cTnT or cTnI are associated with higher risk of death and recurrent ischemic events compared with patients with a low Troponin level.

It was reported that cTnI has low sensitivity in the early hours of $\mathrm{ACS}^{(30)}$. In the present study, both cTnI and CK-MB had highest sensitivity (59\%) on admission to ICU, while after 24 hours cTnI showed highest sensitivity ( $85 \%$ ) and after 48 hours LDH showed highest sensitivity (77 \%). The percent specificity for all the cardiac markers was $100 \%$.

From all biochemical markers detected, in the present study, cTnI was the most sensitive and specific one. Such finding correlated with that of Cubrilo-Turek et al. ${ }^{(5)}$ who reported that cTnI showed best discrimination and accuracy in the assessment of ACS. Also, it was reported that measurement of cTnI in serum has replaced classical biochemical markers, such as $\mathrm{CK}-\mathrm{MB}^{(31)}$.

From the result of the present study it could be concluded that cardiac Troponin I is the most preferred biochemical marker for diagnosis of ACS because of its high specificity and sensitivity. Also, it was a better marker for detection of ACS than Total-CK and its MB-Isoenzyme and Total LDH for all groups (STEMI, NSTEMI and UA). For STEMI group, it was found that persistent increase in cTnI after 48 
hours of admission to ICU indicated bad prognosis and aggravation of the disease. Total LDH could not be used in early detection of ACS because it achieved highest sensitivity only after 48 hours after admission of the patients to ICU, it is reserved only for the late detection when needed.

\section{REFERENCES}

1. Van Domburg RT, Cobbaert C, Kimman GJ, Zerback $R$ and Simoons ML (2000). Long-term prognostic value of serial Troponin $\mathrm{T}$ bedside tests in patients with acute coronary syndrome. Am. J. cardiol, 86(6): 623-627.

2. Grech ED and Ramsdale DR (2003). Acute coronary syndrome: Unstable angina and non-ST segment elevation myocardial infarction. BMJ, 326: 1259-1261.

3. Lakka HM, Laaksonen DE, Lakka TA, Niskanen LK, Kumpusalo E, Tuomilehto J and Salonen JT (2002). The metabolic syndrome and cardiovascular disease mortality in middle-aged men. JAMA. 288 (21):2709-2716.

4. Brobbey $A$ and Ravakhah $K$ (2004). Elevated serum cardiac Troponin I level in a patient after a grand mal seizure and with no evidence of cardiac disease. Am. J. Med. Sci, 328(3):189-191.

5. Cubrilo-Turek M, Topic E, Stefanovic M, Simundic AM, Kern J and Pilas V (2004). New biochemical markers in the assessment of minor myocardial damage in critically ill patients.
Acta Med. Croatica 58(5): 381388.

6. Roberts R, Gowda KS, Ludbrook PA and Sobel BE (1975). Specificity of elevated serum MB Creatine phosphokinase activity in the diagnosis of acute myocardial infarction. Am. J. Cardiol, 36: 433-437.

7. Reis CJ, Kuafman UW, Horowitz GL and Pasternak RC (1988). Usefulness of lactate dehydrogenase and lactate dehydrogenase isoenzymes for diagnosis of acute myocardial infarction. Am J Cardiol. 61: 754758.

8. Plebani $M$ and Zanimotto $M$ (1999): Cardiac markers present and future. Int. J. Clin. Lab, 20: 56-63.

9. Sato $Y$, Yamada $T$, Taniguchi $R$ (2000). Persistently elevated serum concentrations of cardiac troponin $\mathrm{T}$ patients with idiopathic dilated cardiomyopathy are predictive of adverse outcomes. Circulation 103: 369-374.

10. Imazio M, Demichelis B, Cecchi E, Belli R, Ghisio A, Bobbio M and Trinchero $R$ (2003). Cardiac Troponin I in acute pericarditis. J. Am. Coll. Cardiol, 42(12): 2144-2148.

11. Lakkireddy DR and Kondur AK (2005). Cardiac Troponin I release in non-ischemic reversible myocardial injury from acute diphtheric myocarditis. Int. J. Cardiol, 98(2): 351-354.

12. Rosalki SB (1977). Enzyme tests for alcoholism. J. Lab. Clin. Chem, 23: 646. 
13. Wu AH and Bowers GN Jr (1982). Evaluation and comparison of immunoinhibition and immunoprecipitation methods for differentiating $\mathrm{MB}$ and $\mathrm{BB}$ from macroforms of Creatine kinase isoenzymes in patients and healthy individuals. Clin. Chem, 28(10): 2017-2021.

14. SCE (1974). The Committee on enzymes of the Scandinavian Society for Clinical Chemistry and Clinical Physiology. Recommended method for the determination of lactate dehydrogenase using Nacetyl cysteine. Scand J Clin. Lab. Invest, 33: 291-306.

15. Uotila $M$, Ruoslahti $E$ and Engvall E (1981). Two-Site Sandwich enzyme immunoassay with monoclonal antibodies to human $\alpha$-fetoprotein. J. Immunol. Methods 42(1): 11-15.

16. Po AL (1998). In (Statistics for Pharmacists) chapter 11. PP.180185.

17. Roongsritong C, Warraich I and Bradley C (2004). Common causes of Troponin elevations in the absence of acute myocardial infarction: incidence and clinical significance. Chest 125(5): 187784.

18. Apple FS (1992). Acute myocardial infarction and coronary reperfusion. Serum cardiac enzymes for 1991s. AJCP. , 97 (2): 217-226.

19. Adams JE, Bodor GS, DavillaRoman VG, Delmez JA, Apple FS, Ladenson JH and Jaffe AS (1993). Cardiac Troponin I: A marker with high specificity for cardiac injury. Circulation 88 : 101-106.

20. Wolf PL (1989). LDH isoenzymes in myocardial disease. Clinic. Lab. Med, 9: 655665.

21. Ramsay J, Shernan S, Fitch J, Finnegan P, Todaro T, Filloon $T$ and Nussmeier NA (2005). Increased Creatine kinase $\mathrm{MB}$ level predicts postoperative mortality after cardiac surgery independent of new Q waves. J Thoracic Cardiovasc. Surg., 129(2): 300-306.

22. Venge $P$, Lagerqvist $B$, Diderholm E, Lindahl $B$ and Wallentin L (2002). Clinical performance of three cardiac Troponin assays in patients with unstable coronary artery disease (a FRISC II Substudy). Am. J. Cardiol. , 89: 1035-1041.

23. Gudmundsson GS, Kahn SE and Moran JF (2005). Association of mild transient elevation of Troponin I levels with increased mortality and major cardiovascular events in the general patient population. Arch. Pathol. Lab. Med., 129(4): 474-80.

24. Romic Z, Mayer $L$ and Kirin $M$ (2004). Biochemical markers in acute coronary syndrome. Acta Med. Croatica 58(2): 111-114.

25. Scirica BM and Marrow DA (2004). Troponins in acute coronary syndromes. Prog. Cardiovasc. Dis., 47(3): 177-188.

26. Bucciarelli-Ducci $C$, Rasile $C$, Proietti P, Mancone M, Volponi C, Vestri $A$ and Fedele $F$ (2004). Troponin I as a specific marker of myocardial injury: 
From theory to clinical practice in the diagnosis of acute coronary syndrome. Coron. Art. Dis., 15(8): 499-504.

27. Jordanova N, Gynogyosi $\mathbf{M}$, Khorsand A, Falkensammer C, Zorn G, Wojata J, Anvari A amd Huber K (2005), New cutoff values of cardiac markers for risk stratification of angina pectoris. Int. J. Cardiol., 99(3): 429-435.

28. Kontos MC, Shah R, Fritz LM, Anderson FP, Tatum JL, Ornato JP and Jesse RL (2004). Implication of different cardiac Troponin I levels for clinical outcomes and prognosis of acute chest pain patients. J. Am. Coll. Cardiol., 43(6): 958-965.

29. Scirica BM and Morrow DA (2003). Troponins in acute coronary syndromes. Semin. Vasc. Med., 3(4): 363-374.

30. Bar-Or D, Thomas GW, BarOr R, Rael $L$ and Winkler JV (2005). Diagnostic potential of phosphorylated cardiac troponin I as a sensitive, cardiac specific marker for early acute coronary syndrome: Preliminary report. Clin. Chem. Acta 362 (1-2): 6570.

31. Berroeta C, Provenchere S, Mongredien A, Lasocki S, Benessiano J, Dehoux $M$ and Philip I (2006). The use of cardiac Troponins ( $\mathrm{T}$ or $\mathrm{I}$ ) measurement in cardiology and various clinical setting. Ann. Fr. Anesth. Reanim., 25(10):10531063. 


\section{قيمة الترويونين القلبى اى كدليل كيموحيوي لامراض الشرايين التاجية الحادة مقارنة مع الالائل الكيموحيوية التقليدية

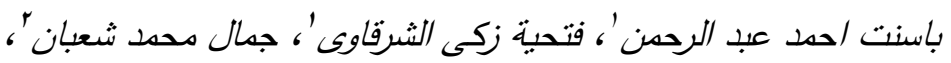

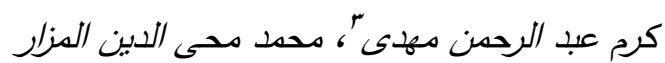

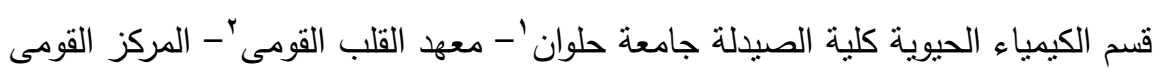

للبحوث (قسم الكيمياء الحيوية الطبية) +- كلية الصيدلة الحامعة البريطانية؛

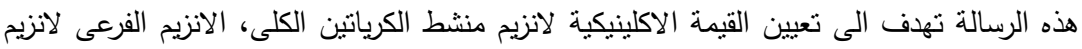

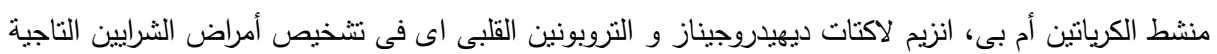
الحادة. وقد أجريت الدراسة على سبعة و عشرون مريضا ممن بعانون من أمراض الثرايين التاجية الحادة من الترائ

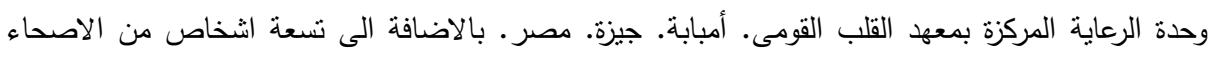

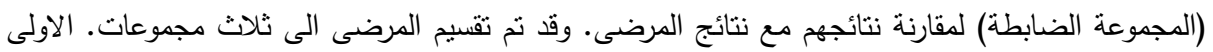

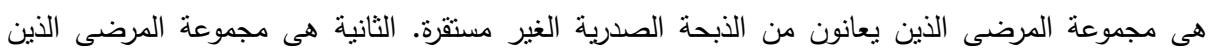

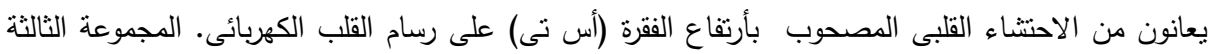

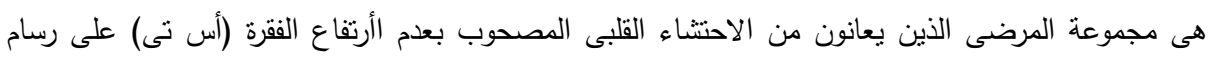

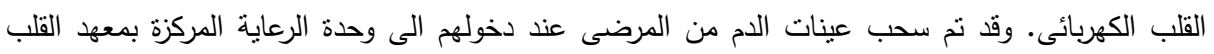

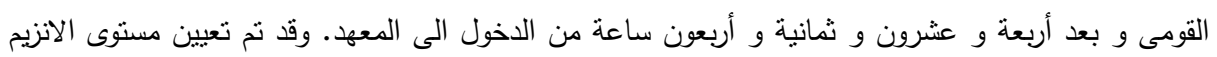

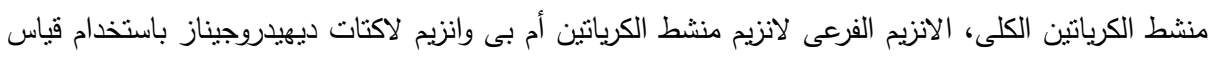

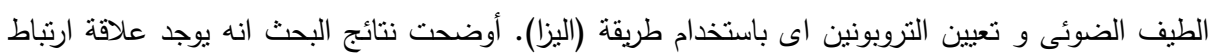

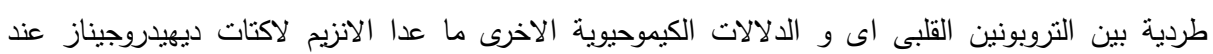

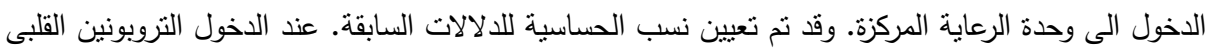
اى والانزيم الفرعى لانزيم هنشط الكرياتين أم بى قد أظهروا اعلى درجة حساسية (تسعة و خمسون بالمائة) و بعد أربعة و عشرون ساعة من الدخول، التزوبونين القلبى الى أظهر اعلى درجة حساسية (خمسة و ثمانون

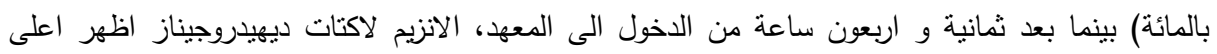

درجة حساسية (سبعة وسبعون بالمائة). وقد كانت نسبة التخصص لجميع الدالالات الكيموحيوية مائة بالمائة.

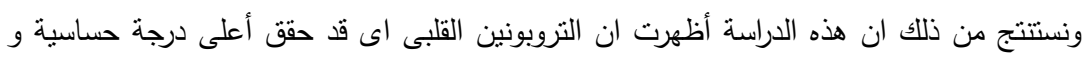

يمكن ان يحل محل الدلالات الكيموحيوية الاخرى (انزيم منشط الكرياتين، الانزيم الفرعى لانزيم منشط الكرياتين التين

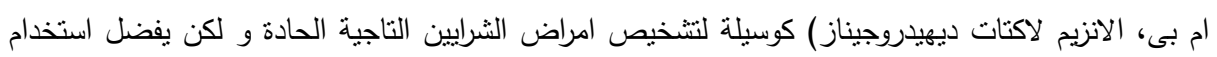
أثتثين من الدلالات فى التشخيص لامراض الثرايين التاجية الحادة. 